\title{
Biochemical and Reproductive Studies on the Effect of
} Gibberellic Acid on Rams

\author{
M. Abdou I; Nour E. M; Hussein E.M. and Eman M. Zaabal
}

Biochemistry Dept., Animal Health Research Institute, Zagazig Lab. Egypt

\begin{abstract}
This study was designed to clarify the effect of the plant growth hormone, gibberellic acid (GA3) on the hematological, biochemical and reproductive profile of rams. Thirty rams were classified into 3 equal groups; a control and two other treated groups; the first one (indirectly exposed group, IEG) was forced to feed on a previously sprayed green fodder (alfalfa) with the recommended dose of GA3, while the second group (directly exposed group, DEG) was forced to drink ad libitum on 75 ppm GA3 in water for 30 successive days followed by another 30 days withdrawal period. Direct exposure to GA3 for one month induced a significant increase in AST, ALT, BUN, creatinine with a significant decrease in testicular size, T4, albumen and testosterone hormone in addition to semen volume, sperm cell concentration, live and motile sperms with normal growth rate, blood picture, TSH, serum total protein and blood glucose level. After one month withdrawal period, creatinine only was returned to its normal value with a significant increase in total sperm abnormalities. However, the indirect exposure to GA3 for one month induced the same deviations with a less severity and non-significant changes in creatinine, moreover, one month withdrawal period ameliorated all deviated parameters except the testicular size, testosterone hormone, $\mathrm{T} 4$, and BUN in addition to reduction the quality of semen. From this study, we can conclude that GA3 has adverse side effects on the biochemical and reproductive profile of rams. These effects were severe in rams directly exposed to the gibberellic acid (DEG) compared to those fed on sprayed green fodder with gibberellic acid (IEG)
\end{abstract}

\section{Introduction}

Gibberellic acid is a plant growth regulator used in many countries including Egypt, to accelerate the growth of fruits and vegetables $(\boldsymbol{E l}$ Mofty et al, 1994) and reach to animals through diet. It is a natural phyto-hormone which produced naturally through biosynthesis of plants as they grow, ensuring that they have the hormones they need to develop normally, and these hormones can also be applied to plants by gardeners and farmers to achieve specific desired outcomes (Fernandez and Rodriguez, 1979). A group of related substances called gibberellins were discovered as a 
metabolic byproduct of fungus Gibberell a Fujikuroi (Grennan, 2006) and also can be readily extracted from common plants (LeoWright, 1993). Gibberellic acid accelerates and improves the yield of a wide variety of plants by increasing cell division (Silverstone and Sun, 2000) and regulating various physiological processes in the plants (Seetharam and Kumari 1975, Abouelmaatti et al, 2012, Eid et al, 2016, Aswathanrayana and Mahadevappa, 1977). Moreover, it is used against harmful agriculture pets to accelerate the growth of fruits and vegetables (Arous et al, 2001).

The early studies of Peck et al. (1957), kimura et al. (1957) and Macgregor (1988) on the toxicological and pharmacological effect of GA3 clearly demonstrated that it was essentially non-toxic when tested by various routes of injections or by oral, ocular or aerosol application in rats, mice, guinea pig, rabbits, cats and dogs. On the other hand, GA3 was reported to have a number of endocrine effects (Gawienowski et al., 1977). Authors have demonstrated that GA3 has estrogenic, androgenic effects and acts synergistically with estradiol. In rats, GA3 elicited an estrogen like response in uteri of ovarictomyized female and keep them in continuous estrous.

GA3 treatment significantly increased erythrocytic count in laboratory mice (Ozmen et al.,
1995). Similarly, it increased Rbcs, $\mathrm{Hb}$ and PCV as well as T.protein, albumen and globulin in Quails $(\boldsymbol{E l}$ Sebai et al, 2003). Moreover, Abdel- Hamid et al (1994) reported that GA3 increased blood glucose level (hyperglycemia) in broiler chicks, however, it had no effect on blood glucose level in quail (ElSebai, et al, 2003).

GA3 had no effect on blood creatinine content or AST but significantly decreased GGT in quail (El-Sebai et al, 2003), however, GA3 was reported to induce kidney failure in treated chicks (Abdelhamid et al, 1994), hepatonephrotoxicity (Hanan et al, 2010) and severe histopathological alterations in kidneys of treated rats (Nassar et al, 2012).

GA3 treatment $(75 \mathrm{ppm}$ ad libitum to rat) induced elevation of plasma AST, ALT, ALP, creatinine while showed non-significant alterations in plasma $\mathrm{T}$. protein, albumen, globulin and glucose (Hanan et al., 2010), however, another study on rats given GA3 showed also a significant increase in serum AST, ALT, urea and creatinine but with a significant decrease in serum $\mathrm{T}$. protein (Hanaa et al., 2013). Moreover, The activity of serum transaminases (GOT and GPT) and ALP was found to increase during the first two weeks of GA3 treatment followed by a marked decrease after the third week (Sakr et al., 2003), while, two weeks withdrawal period did not ameliorate the negative pathological 
effects in different organs of two weeks old broiler chicks fed on GA3 containing diet (25-125 ppm) for two weeks (Abdelhamid et al., 1994) and even one month withdrawal period failed to return the negative pathological changes due to direct GA3 treatment in rabbits (Abdou et al., 2016). Regarding to the semen evaluation and testosterone hormone concentration, male rabbits treated with GA3 at all studies doses caused a significant increase in semen ejaculate volume, sperm concentration, total sperm output and sperm motility and has direct androgen like action on testes compared to the control (Kamel et al., 2009). Similar results were recorded with decreased serum testosterone level in rats (El-Komy, 2003). On the other hand, Nassar et al. (2012) recorded that a single oral daily dose of $500 \mathrm{mg}\left(1 / 3 \mathrm{LD}_{50}\right) / \mathrm{kg}$ GA3 for 6 continuous days in rats induced sperm abnormalities, however, testicular changes including Leydig's cell degeneration, reduction in seminiferous tubules and necrotic symptoms and sperm degeneration were recorded in GA3 treated rats (Hanaa et al., 2013).

This study aimed to evaluate the biochemical and reproductive changes that may be associated with direct or indirect exposure to the plant growth hormone, gibberellic acid. The indirect exposure was designed through feeding of green foods previously sprayed with it, while, the direct exposure was applied through forcing of animals to drink ad libitum on $75 \mathrm{ppm} \mathrm{GA3}$ in water for 30 successive days.

\section{Material and methods:}

\section{Animals:}

Thirty sexually mature rams weighing 40-60 $\mathrm{kg}$ were used. Rams were kept in 3 yards for one week before beginning the experimental work. They were maintained on a standard diet and water ad libitum.

\section{Materials:}

Berelex $^{\mathrm{R}}$ tablet: Each tablet weighing $10 \mathrm{gm}$ contains $10 \% \mathrm{GA} 3$ and manufactured by Valent BioSciences Corporation.

\section{Experimental design:}

Animals were divided into 3 equal groups; G1: Left without treatment and considered as a control. G2: The first treated group (indirectly exposed group, IEG) was forced to feed on a previously sprayed alfalfa with the recommended dose of GA3. One tablet Berelex ${ }^{\mathrm{R}} 10 \%$ dissolved in 80 liter water was enough to spray 8 kerate alfalfa. However, G3: The second treated group (directly exposed group, DEG) was forced to drink $75 \mathrm{ppm}$ GA3 in water ad libitum for 30 successive days (Hanan et al., 2010 and Mona and Wafaa, 2010). The control and the second treated group (directly exposed group, DEG) were fed on non-sprayed alfalfa all over the day hours with a standard concentrated diet for all groups at the night hours. Rams were 
subjected to biochemical and reproductive evaluation after thirty days treatment period and reevaluated after another thirty days (withdrawal period).

\section{Clinical examination of Rams:}

All rams were weighed at the beginning of the experiment and monthly thereafter for three times to evaluate the growth rate. The testicular dimensions (length, width and thickness) were measured using the caliber to estimate the testicular size as described by $\boldsymbol{E l}-\boldsymbol{A} \boldsymbol{z} \boldsymbol{a} \boldsymbol{b}$ (1977).

\section{Biochemical studies:}

\section{Blood samples:}

Two blood samples were collected from the jugular vein of each animal. The first one was collected on heparin as anticoagulant for blood picture estimation (Jain, 2000), while the second blood sample was collected without addition of anticoagulant for separating the serum for determination of serum total protein (Peters, 1968), albumin (Baure, 1982), serum Alanine aminotransferase (ALT) and Aspartate aminotransferase (AST) (Reitman and Frankel, 1957, NaderShalaby et al., 2012), urea (Patton and Crouch, 1977), glucose (Trinder, 1969) and Creatinine (Husdan and Rapport, 1968). Testosterone hormone was also measured by radioimmunoassay kits (Diagnostic Product Company, LOS Angeles, USA). Blood samples were collected from all animals at the end of treatment period and 30 days after.

\section{Semen analysis:}

Semen collection and evaluation was carried out according to Laing (1979).

Data were statistically analyzed using ANOVA test according to Snedecor and Cochran (1976)

\section{Results and discussion}

Gibberellins reach the animals through diet and through drinking water (Tomlin, 2004). Table (1) revealed that GA3 did not affect the growth rate of the treated rams in agree with Ustan et al. (1992) who found that GA3 did not affect the litter size or number when consumed by pregnant dams on the contrary to Troudi et al. (2010) who found that GA3 intake by dams during 21 days induced a significant increase in body weight of mothers and their offspring and explained their results to either the increase of food intake by lactating rats or/and by an increase of mitotic division induced by GA3. However, GA3 was reported to accelerate the growth rate as well as increases blood calcium level of rats (Csaba et al., 1977), had positive influence on body weight and food conversion rate on mice and rat (Olsen, 1981 and Ravikumar and Srikumar, 2005) and the long term use of high levels of GA3 for 22 months to mice induced a significant increase in their body weights but induced tumors (ElMofty et al., 1994). Table (2) 
revealed also that GA3 did not affect blood picture in the contrary to Ozmen et al. (1995); El-Sebai, et al (2003) and Muthu et al ( 2011) who reported a significant improvement in different parameters of blood picture compared to the control in lab mice, quails and male albino rats, respectively.

Alterations in biochemical as well as haematological parameters may be considered toxicity indices of compounds/drugs as a result to their chronic use. Table (3) showed significant increase in AST, ALT accompanied by a significant decrease in albumen was reported in this study due to liver toxicity in agree with that reported by Hanan et al. (2010) who recorded a hepatotoxic effect due to GA3 and concluded that rat treated with 75 ppm GA3 ad libitum significantly increase AST, ALT and ALP but did not alter plasma $T$. protein, albumen or globulin and agree also with Troudi et al. (2010) who showed that GA3 is hepatotoxic and causes histopathological changes in the liver of rats and their neonates. Similarly, Muthu et al., (2011) found that GA3 produced a significant increase in AST in rats and Hanaa and Maisaa (2013) reported a significant increase in AST, ALT with a significant decrease in $\mathrm{T}$. protein in serum of rats given GA3. The observed disturbances in liver enzymes associated with GA3 treatment may be attributed to the harmful effect of plant growth regulator (GA3) on the liver and muscle tissue cell membrane resulting in structural damage and leakage of the enzymes in the serum (Tuluce and Celik, 2006) and augmented by the previously reported histopathological changes in the liver of rabbits (Abdou et al., 2016). Serum transaminases were considered to be a sensitive measure in evaluating hepatocellular damage (Nasr-Esfahani et al., 2001), however, the decrease in albumen perhaps due to the decrease in its manufacture in liver cells. Our results disagree with $\boldsymbol{E l}$-Sebai et al. (2003) who found a significant increase in $\mathrm{T}$. protein, albumen and globulin in quail, and disagree also with Abdelhamid et al. (1994) and Vesely et al. (1995) who reported an increase in serum $\mathrm{T}$. protein and attributed their results to dehydration and increased RNA and protein synthesis, respectively.

This study revealed a significant increase in BUN and creatinine due to GA3 exposure which reflect the side effect of GA3 on the kidneys. Similarly, Troudi et al. (2011) showed that GA3 is nephrotoxic and causes histopathological changes in the kidney of rats and their neonates and augmented by the previously reported histopathological changes in the kidney of rabbits (Abdou et al., 2016). Our results agree also with Hanan et al. (2010) who reported a significant elevation in creatinine in rats treated with $75 \mathrm{ppm}$ GA3 ad 
libitum with nephrotoxicity by histopathology and Hanaa et al. (2013) who found that rats given GA3 showed a significant increase in both urea and creatinine and attributed the increased blood urea to the increased protein catabolism in mammalian body. BUN is produced endogenously by tissue creatinine breakdown, and the increase in serum creatinine level depended upon the glomerular filtration rate. However, when creatinine excretion failed to balance the production, serum creatinine level increased (Chesbrough and McArthur, 1972). Indeed, creatinine and BUN are the only parameters used for determination of nephrotoxicity. On the contrary, El-Sebai et al. (2003) reported that GA3 had no effect on blood creatinine content in quail. Moreover, Muthu et al. (2011) found that there is a substantial reduction in the quantity of urea, creatinine of male albino rat treated with GA3 compared to the control. This study, (Table, 3 ) revealed nonsignificant changes in blood glucose due to GA3 exposure. Similar result was reported in quails (El-Sebai et al., 2003) and rats (Hanan et al., 2010), meanwhile, a non-significant hyperglycemia was reported in chick treated with GA3 (Abdelhamid et al., 1994). On the contrary, a progressive decrease in the quantity of glucose was noted at all doses of GA3 treatment on rats (Muthu et al., 2011) and they attributed the hypoglycemia to the increased glucose utilization by cells resulting in greater glucose entry into the cells of each tissue. Regarding to the hormonal study, table (4) revealed that GA3 significantly decreases testosterone hormone. This result is augmented with the previous result of Leydig's cell degeneration in GA3 treated rats (Hanaa et al., 2013) and rabbits (Abdou et al., 2016). However, GA3 stimulates the growth of the comb in the male chicks (Gawienowski et al., 1977) and inspite of the significantly decreased testosterone concentration in rats (El-Komy, 2003) and male rabbits (Kamel et al., 2009), they suggested that GA3 has a direct testosterone like action as it inhibits the testosterone secretion and replace it in its action manifested by the recorded improvement in semen quantity and quality by them. The long term use of high levels of GA3 in our study, table (1), induced a significant decrease in testicular size similar to the result reported in male albino rats (El-mofty and Sakr, 1988), in addition to decreasing the weight of the testes inspite of increasing the animals growth rate (Csaba et al, 1977). Indeed, the size of testes directly reflects the quantity of spermatogenic tissue they contain, and so the recorded significant decrease in testicular size indicates the reduced ability to produce sperm (Knight, 1977 and Lincoln, 1998) and the decreased testicular 
size is an indicator for the testicular atrophy.

Regarding the semen evaluation of both groups, (table, 4) revealed that GA3 induced a significant decrease in semen volume, sperm cells concentration, live and motile sperms at the end of the treatment period, however, a significant increase in the sperm abnormalities was recorded one month after the end of the treatment period in both groups. GA3 may serve as an inhibitor of testicular cell function (Ravikumar and Srikumar, 2005) and one dose of $500 \mathrm{mg}\left(1 / 3 \mathrm{LD}_{50}\right) /$ $\mathrm{kg}$ GA3 for 6 days induced a significant increase in sperm abnormalities in the form of coiled tail, detached head and other abnormalities (Nassar et al., 2012). On the other hand, our results disagree with El-Komy (2003) and Kamel et al (2009) who reported that GA3 caused a significant increase in semen ejaculate volume, sperm cell concentration, live sperm and motility with a significant decrease in sperm abnormality of rats and male rabbits, respectively compared to the control.

The recorded decrease in sperm cell count and the percentage of live sperm in rats treated with GA3 could be attributed to the decreased testosterone which necessary for the early stages of spermatogenesis (Sharpe et al., 1988). Testosterone is important for mitosis and differentiate the rounded spermatid to be elongated, so that the recorded decreased hormone level increased the immature sperm (O'Donnell et al., 1994 and Sun et al., 1990). Our results augmented by the histological studies of Ravikumar and Srikumar (2005) and Abdou et al (2016) who reported that GA3 induced loss of germ cells and reduction in the size of the seminiferous tubules with decreased sperm count in the lumen and dystrophy of Leydig cell.

Our study (table, 3) revealed also a significant decrease in serum $\mathrm{T} 4$ in GA3 treated rams (DEG). This result came in accordance with Troudi et al, (2010) who reported a significant decrease in plasma T3 and T4 levels in treated dams and their pups and were more pronounced in pups than in dams comparatively to those of the control group, moreover, GA3 provokes a significant increase in relative thyroid gland weight of pups that was consistent with the decrease of plasma thyroid hormone levels. Similarly, kobal et al. (2000) that 2, 4-dichlorophenoxyacetic acid, another plant growth regulator used in agriculture as a selective herbicide, reduced serum $\mathrm{T}_{3}$ in adult rats of both sexes.

The present study (table, 2) revealed that the adverse side effect of GA3 on liver was mostly reversible in IEG while one month withdrawal period failed to return the deviated parameters to their normal values in DEG. Similarly, Sakr et al. (2003) reported a significant increase in the activity of GPT, GOT and ALP after two 
weeks exposure but they also reported a marked decrease after the third week and attributed the decreased enzyme activities after the third week to the hepatotoxic potency of GA3 which led to severe destructive changes in the hepatic cells and indicating irreversible effect. However, feeding chicken with GA3 led to lesions in different tissues that renormalized following withdrawal (Wafaa et al., 2011) of the compound, indicating that the effect of GA3 in animal tissues is reversible. However, GA3 produced dose dependent on different parameters of rat blood serum (Muthu et al, 2011). These differences in results may be attributed to the sensitivity of the species, the different doses and the length of the treatment period.

This study concluded that GA3 has adverse side effects on the biochemical and reproductive profile of rams. These effects were severe in rams directly exposed to the hormone (DEG) compared to those fed on sprayed green fodder with its recommended dose (IEG).

Table (1): Body weight and testicular size of rams directly (DEG) or indirectly (IEG) treated with GA3 after one month treatment and after withdrawal period $(n=5)$.

\begin{tabular}{|l|c|c|c|c|c|}
\hline \multicolumn{1}{|c}{ Time } & \multicolumn{3}{c|}{ IEG } & \multicolumn{2}{c|}{ DEG } \\
\cline { 2 - 6 } parameter & $\begin{array}{c}\text { Before } \\
\text { treatment }\end{array}$ & $\begin{array}{c}\text { After } \\
\text { treatment }\end{array}$ & $\begin{array}{c}\text { After } \\
\text { withdrawal }\end{array}$ & $\begin{array}{c}\text { After } \\
\text { Treatment }\end{array}$ & $\begin{array}{c}\text { After } \\
\text { withdrawal }\end{array}$ \\
\hline $\begin{array}{l}\text { Body weight } \\
\text { (Kg) }\end{array}$ & $46.2 \pm 2.08^{\mathrm{b}}$ & $51.9 \pm 2.11^{\mathrm{b}}$ & $58.2 \pm 2.32^{\mathrm{a}}$ & $52.3 \pm 1.61^{\mathrm{ab}}$ & $58.4 \pm 1.96^{\mathrm{a}}$ \\
\hline $\begin{array}{l}\text { Weight gain } \\
\text { (Kg/month) }\end{array}$ & -------- & $5.7 \pm 0.37$ & $6.3 \pm 0.25$ & $5.5 \pm 0.32$ & $6.1 \pm 0.37$ \\
\hline Testicular size & $94.56 \pm 0.89^{\mathrm{a}}$ & $87.26 \pm 0.96^{\mathrm{b}}$ & $78.46 \pm 1.76^{\mathrm{cd}}$ & $81.36 \pm 1.65^{\mathrm{c}}$ & $76.32 \pm 1.57^{\mathrm{d}}$ \\
\hline
\end{tabular}

Values with different litters within the same raw significantly different using Duncan Multiple Range Test at $\mathrm{p}<0.05$

(IEG= indirect exposed group, $\mathrm{DEG}=$ direct exposed group.)

Table (2): Blood picture of rams directly (DEG) or indirectly (IEG) treated with GA3 after one month treatment and after withdrawal period $(n=5)$.

\begin{tabular}{|l|c|c|c|c|c|}
\hline \multirow{2}{*}{ Time } & \multicolumn{3}{c|}{$\begin{array}{c}\text { First assay } \\
\text { (After treatment period) }\end{array}$} & \multicolumn{2}{c|}{$\begin{array}{c}\text { Second assay } \\
\text { (After withdrawal period) }\end{array}$} \\
\cline { 2 - 6 } Parameter & Control & IEG & DEG & IEG & DEG \\
\hline Rbcs( x10 $/$ ul) & $9.25 \pm 0.07$ & $9.32 \pm 0.25$ & $9.76 \pm 0.08$ & $9.32 \pm 0.14$ & $9.46 \pm .16$ \\
\hline Hb(gm/dl) & $9.33 \pm 0.26$ & $9.07 \pm 0.21$ & $8.87 \pm 0.37$ & $9.28 \pm 0.28$ & $9.44 \pm 0.17$ \\
\hline PCV \% & $28.83 \pm 0.44$ & $30.00 \pm 1.00$ & $30.33 \pm 1.33$ & $29.67 \pm 0.88$ & $29.67 \pm 0.33$ \\
\hline TLC $(\mathbf{x 1 0}$ / $/ \mathbf{u l})$ & $8.35 \pm 0.20$ & $8.28 \pm 0.15$ & $8.10 \pm 0.18$ & $8.22 \pm 0.44$ & $7.98 \pm 0.25$ \\
\hline Lymphocyte (\%) & $54.5 \pm 0.65$ & $51.25 \pm 0.45$ & $56.42 \pm 0.79$ & $56.1 \pm 0.74$ & $52.00 \pm 1.41$ \\
\hline Neutrophil (\%) & $40.25 \pm 0.85$ & $44.0 \pm 0.78$ & $39.20+0.73$ & $39.92 \pm 0.87$ & $43.00 \pm 1.41$ \\
\hline Monocyte (\%) & $3.5 \pm 0.50$ & $3.0 \pm 0.41$ & $2.74 \pm 0.22$ & $2.56 \pm 0.31$ & $3.25 \pm 0.48$ \\
\hline Eosinophil (\%) & $1.75 \pm 0.25$ & $1.75 \pm 0.48$ & $1.64 \pm 0.47$ & $1.42 \pm 0.12$ & $1.75 \pm 0.48$ \\
\hline Basophil (\%) & 0.00 & 0.00 & 0.00 & 0.00 & 0.00 \\
\hline
\end{tabular}


Values with different litters within the same raw significantly different using Duncan Multiple Range Test at $\mathrm{p}<0.05$. (IEG $=$ indirect exposed group, $\mathrm{DEG}=$ direct exposed group.)

Table (3): Biochemical parameters of rams directly (DEG) or indirectly (IEG) treated with GA3 after one month treatment and after withdrawal period $(n=5)$.

\begin{tabular}{|l|l|l|l|l|l|}
\hline \multirow{2}{*}{$\begin{array}{c}\text { Time } \\
\text { Parameter }\end{array}$} & \multicolumn{3}{|c|}{$\begin{array}{c}\text { First assay } \\
\text { (After treatment period) }\end{array}$} & \multicolumn{2}{c|}{$\begin{array}{c}\text { Second assay (After } \\
\text { withdrawal period) }\end{array}$} \\
\cline { 2 - 6 } & Control & IEG & DEG & IEG & DEG \\
\hline Total protein (g/dl) & $6.96 \pm 0.17$ & $6.86 \pm 0.20$ & $6.54 \pm 0.12$ & $6.74 \pm 0.13$ & $6.52 \pm 0.16$ \\
\hline Albumin (g/dl) & $3.60 \pm 0.02^{\mathrm{a}}$ & $3.25 \pm 0.04^{\mathrm{c}}$ & $3.42 \pm 0.07^{\mathrm{b}}$ & $3.50 \pm 0.04^{\mathrm{ab}}$ & $3.36 \pm 0.04^{\mathrm{bc}}$ \\
\hline AST(u/l) & $89.8 \pm 1.71^{\mathrm{b}}$ & $140.4 \pm 6.37^{\mathrm{a}}$ & $139.4 \pm 3.59^{\mathrm{a}}$ & $97.4 \pm 1.72^{\mathrm{b}}$ & $134.6 \pm 6.01^{\mathrm{a}}$ \\
\hline ALT(u/l) & $19.6 \pm 1.78^{\mathrm{b}}$ & $34.4 \pm 4.86^{\mathrm{a}}$ & $33.4 \pm 3.43^{\mathrm{a}}$ & $25.0 \pm 1.39^{\mathrm{b}}$ & $32.2 \pm 2.08^{\mathrm{a}}$ \\
\hline BUN(mg/d) & $5.46 \pm 0.22^{\mathrm{b}}$ & $9.02 \pm 0.35^{\mathrm{a}}$ & $9.8 \pm 0.6^{\mathrm{a}}$ & $8.03 \pm 0.1^{\mathrm{a}}$ & $8.86 \pm 0.4^{\mathrm{a}}$ \\
\hline Createnine(mg/dl) & $0.84 \pm 0.02^{\mathrm{b}}$ & $0.88 \pm 0.11^{\mathrm{b}}$ & $1.06 \pm 0.07^{\mathrm{a}}$ & $0.85 \pm 0.03^{\mathrm{b}}$ & $0.87 \pm 0.06^{\mathrm{b}}$ \\
\hline Blood sugar (mg/dl) & $63.4 \pm 2.54^{\mathrm{b}}$ & $62.6 \pm 1.5^{\mathrm{b}}$ & $60.2 \pm 4.24$ & $61.2 \pm 1.74$ & $58.8 \pm 3.6$ \\
\hline TSH(ng/dl) & $0.46 \pm 0.03^{\mathrm{a}}$ & $0.41 \pm 0.07$ & $0.42 \pm 0.02$ & $0.42 \pm 0.05$ & $0.43 \pm 0.03$ \\
\hline T3(ng/dl) & $0.57 \pm 0.03$ & $0.54 \pm 0.02$ & $0.50 \pm 0.02$ & $0.56 \pm 0.03$ & $0.53 \pm 0.01$ \\
\hline T4(ng/dl) & $63.62 \pm 2.49^{\mathrm{a}}$ & $60.00 \pm 0.89^{\mathrm{ab}}$ & $50.8 \pm 2.78^{\mathrm{c}}$ & $59.42 \pm 0.54^{\mathrm{ab}}$ & $53.80 \pm 2.73^{\mathrm{bc}}$ \\
\hline Testosterone(ng/dl) & $5.7 \pm 0.35^{\mathrm{a}}$ & $3.26 \pm 0.38^{\mathrm{b}}$ & $2.17 \pm 0.17^{\mathrm{c}}$ & $3.09 \pm 0.42^{\mathrm{b}}$ & $1.91 \pm 0.11^{\mathrm{c}}$ \\
\hline
\end{tabular}

Values with different litters within the same raw significantly different using Duncan Multiple Range Test at $\mathrm{p}<0.05$. (IEG $=$ indirect exposed group, $\mathrm{DEG}=$ direct exposed group.)

Table (4): Semen picture of rams directly (DEG) or indirectly (IEG) treated with GA3 after one month treatment and after withdrawal period $(n=5)$.

\begin{tabular}{|c|c|c|c|c|c|}
\hline \multirow{2}{*}{ Time } & \multicolumn{3}{|c|}{$\begin{array}{c}\text { First assay } \\
\text { (After treatment period) }\end{array}$} & \multicolumn{2}{c|}{$\begin{array}{c}\text { Second assay (After withdrawal } \\
\text { period) }\end{array}$} \\
\cline { 2 - 6 } Parameter & Control & IEG & DEG & IEG & DEG \\
\hline Semen volume(ml) & $1.14 \pm 0.09 \mathrm{a}$ & $0.64 \pm 0.05 \mathrm{~b}$ & $0.50 \pm 0.04 \mathrm{bc}$ & $0.38 \pm 0.04 \mathrm{~cd}$ & $0.28 \pm 0.04 \mathrm{~d}$ \\
\hline Concentration(X109) & $2.23 \pm 0.12 \mathrm{a}$ & $1.48 \pm 0.13 \mathrm{~b}$ & $1.32 \pm 0.11 \mathrm{~b}$ & $0.72 \pm 0.07 \mathrm{c}$ & $0.31 \pm 0.08 \mathrm{~d}$ \\
\hline Live sperm\% & $88.8 \pm 1.36 \mathrm{a}$ & $83.4 \pm 0.93 \mathrm{~b}$ & $79.8 \pm 0.66 \mathrm{~b}$ & $72.0 \pm 2.14 \mathrm{c}$ & $65.2 \pm 1.66 \mathrm{~d}$ \\
\hline Motility \% & $80.0 \pm 3.16 \mathrm{a}$ & $58.0 \pm 2.00 \mathrm{~cd}$ & $56.0 \pm 2.45 \mathrm{~d}$ & $64.0 \pm 2.45 \mathrm{bc}$ & $66.0 \pm 2.45 \mathrm{~b}$ \\
\hline Total abnormalities\% & $6.6 \pm 0.81 \mathrm{~b}$ & $8.2 \pm 0.73 \mathrm{~b}$ & $9.60 \pm 1.03 \mathrm{~b}$ & $16.2 \pm 0.86 \mathrm{a}$ & $19.8 \pm 1.24 \mathrm{a}$ \\
\hline Primary abnormalities\% & $0.6 \pm 0.24$ & $0.8 \pm 0.37$ & $1.00 \pm 0.45$ & $1.4 \pm 0.24$ & $1.60 \pm 0.24$ \\
\hline
\end{tabular}

Values with different litters within the same raw significantly different using

Duncan Multiple Range Test at $\mathrm{p}<0.05$. (IEG $=$ indirect exposed group,

$\mathrm{DEG}=$ direct exposed group.)

\section{References}

Abdelhamid, A.M.; Dorra T.M.; Ali, M.A. and Abou-Egla, E.H. (1994): Effect of gibberellic acid on broiler chickens performance and some metabolic parameters. Archiv fur Tierernaehrung, 46 (3): 269 276.

Abdou MA, Ayoub MA and ElAalem MM (2016): Cytogenetic and pathological studies on the effect of gibberellic acid in rabbit. Egyption journal of chemistry and 
environmental health, 1 (1): 821 835.

Abouelmaatti R. R., Algammal, A. M., Li, X., Ma, J., Abdelnaby, E. A. and Elfeil, W. M. Cloning and analysis of Nile tilapia Toll-like receptors type-3 mRNA. - Central European Journal of Immunology 38: 277-282.

Arous S, Boussaid $M$ and Marrakchi M (2001): Plant regeneration from zygotic embryo hypocotyls of Tunisian chilli (Capsicum annuum L.). J Appl Hortic, 3:17-22.

Aswathanrayana

Mahadevappa SC and M. (1977): Determination of optimum stage of gametocyte application in inducing pollen sterility for production of hybrid rice.

Mysore J Agric Sci., 25(3): 284287.

Baure, J.D. (1982): Colorimetric determination of albumin. Clinical laboratory methods, $9^{\text {th }}$ ed., 495496.

Chesbrough $M$ and McArthur $J$. (1972): In: A laboratory manual for rural tropical hospitals. The English Language Book Society and Churchil Livingstone, London, P.145.

Csaba G, Darvas S and László V. (1977): Effects of treatment with the plant hormone gibberellin on neonatal rats. Acta Biol Med Ger., 36(10): 1487-1488.

El-Azab, AI (1977): Effect of some factors on semen production in buffalo bulls. M.V.Sc., Thesis, Cairo University.
Elkomy A.E. (2003): Physiological studies on gibberellic acid $\left(\mathrm{GA}_{3}\right)$ and reproductive functions of adult fowl. Ph.D.Thesis. Faculty of Agriculture, Alexandria University. El-Mofty MM and Sakr SA. (1988): Introduction of neoplasms in the Egyptian Toad by gibberellin A3. Oncology; 45:61-64.

El-Mofty MM, Sakr SA, Rizk AM and Moussa EA (1994): Carcinogenic effect of gibberellin A3 in Swiss Albino mice. Nutr Cancer, 21(2): 183-190.

El-Sebai, A., M. Abaza, and S.A. Elnagar (2003): Physiological effects of gibberellic acid (GA3) on female Japanese quail production and reproduction. Egyptian Poultry Science, 23: 977 - 992.

Fernandez, E. and Rodriguez, $M$. (1979): Effect of indole acetic and gibberellic acids on paramylon synthesis in Euglena gracilis. Microbiol Esp., 80; 32-33:11-20.

Gawienowski AM, Stadnicki SS and Stacewicz-Sapuntzakis $M$. (1977): Androgenic properties of gibberellic acid in the chick comb bioassay. Experientia, 33(11): 15441545.

Grennan AK (2006): Gibberellin metabolism enzymes in rice. Plant Physiol., 141:524-526.

Hanaa, A.H.; Isa, A.M.; Wafaa, M. E. and Samar, E. N. (2013): Testicular disorders induced by plant growth regulators: cellular protection with proanthocyanidins grape seeds extract. Cytotechnology, 65:851-862. 
Hanaa A. H and Maisaa M. A. (2013): Grape seeds proanthocyanidin extract as a hepatic-reno-protective agent against gibberellic acid induced oxidative stress and cellular alterations. Cytotechnology, 65:567-576

Hanan, A.E.S.; Mona, M.M. and Hany, M.H. (2010): Biochemical and molecular profiles of gibberellic acid exposed albino rats. Journal of American Sci., 11: 1823.

Husdan, H. and Rapaport (1968): Colorimetric method for determination of creatinine. Clin. Chem., 14: 222-226.

Jain, N. C. (2000): "Schalm's veterinary hematology" $8^{\text {th }}$ ed. Lea and Febiger, Philadelphia, U.S.A

Kamel, K.I.; Elkomy, A.E. and El-Sbeiy, M.E. (2009): The androgenic action of gibberellic acid (GA3) on reproductive performance of New Zealand white rabbit bucks. World Journal of Agric. Sci., 1: 40-48.

Kimura, E.T., R.K. Yaung and K. stanistwsh (1957): Gibberellic acid: Toxicological and pharmacological studies. J. Am. Pharm. Assoc., 48: 127-129.

Knight, T.W. (1977): Methods for the indirect estimation of testes weight and sperm numbers in Merino and Romney rams. New Zealand Journal of Agri-cultural Research, 20, 291-296.

Kobal, S., Kadunc, N. C., and Cestnik, V. (2000): Serum $\mathrm{T}_{3}$ and $\mathrm{T}_{4}$ concentrations in the adult rats treated with herbicide 2,4dichlorophenoxyacetic acid. Eur. J. Physiol. 440, 171-172.

Laing, J. A. (1979): Fertility and Infertility in Domestic Animals. ${ }^{\text {rd }}$ ed. Bailliere Tindall, London.

LeoWright, O. (1993): Gibberellins: plant growth hormone, Practical hydroponics and greenhouses, Issue (11): 1-4.

Lincoln, G.A. (1998):

Reproductive seasonality and maturation throughout the complete life-cycle in the mouflon ram (Ovis musimon).Animal Reproduction Science, 53, 87-105.

Macgregor, R.C. (1988): In: Haresign, W. and Cole, D.J.A. (Eds.), Recent Development in Ruminant Nutrition. Butterworths.

Mona, G.A. and Wafaa, F. H. (2010): Influence of Gibberellic Acid (GA3) on Renal Cortex of Adult Male Albino Rats (Histological, Imunohistochemical and Biochemical Study). Egypt. J. Histol., 33 (4): 767 - 780.

Muthu, S; Muthuraman,P; Muthuviveganadavel, $V$ and Srikumar,K (2011): Acute effect of gibberellic acid on serum enzymes and blood markers in male albino rats. International journal of drug delivery, 3: 340-347.

Nasr-Esfahani MH, Razavi S and Mardani M. (2001): Relation between different human sperm nuclear maturity tests and in vitro fertilization. J Assist Reprod Genet, 18(4): 221-227.

Nassar SA, Zayed FA, Hegab AM, Mossaad MN and Harfoush 
AS (2012): Cytogenetic, histological and histochemical studies on the effect of gibberllin A3 in albino rats. $J$ Am Sci, 8(1): 608-622.

O'Donnell L, McLachlan RI, Wreford NG, et al. (1994): Testosterone promotes the conversion of round spermatids between stages VII and VIII of the rat spermatogenic cycle. Endocrinology, 135(6): 2608-2614.

Olsen P. (1981): The stimulating effect of phytohormone, gibberellic acid, on reproduction of Mus musculus. Aust Wildl Res; 8(2): 321-325.

Ozmen M, Topçuogolu SF, Bozcuk S and Bozcuk NA (1995): Effects of abscisic acid and gibberellic acid on sexual differentiation and some physiological parameters of laboratory mice. Tr J Biol., 19:357364.

Patton, C.S. and crouch, S.R. (1977): Enzymatic determination of urea. Anal chem., 49: 464-469.

Peck, H.M., S.E. McKinney, A. Tyrell and B.G. Byham (1957): Toxicological evaluation of the geberellic acid. Science, 126: 10641065.

Peters, T. (1968): Colorimetric method for determination of total protein. Clin. Chem., 17: 1147.

Ravikumar S and Srikumar K. (2005): Metabolic dysregulation and inhibition of spermatogenesis by gibberellic acid in rat testicular cells. J Environ Biol, 26(3): 567569.
Reitman S and Frankel S (1957): Colorimetric estimation of serum transaminases. Am J Clin Path., 28:56-63.

Sakr, S.; Okdaha, A. and Sabah, F. El-Abd (2003): Gibberellin A3 induced histological and histochemical alterations in the liver of albino rats. Science Asia, 29: 327-331.

Seetharam A and Kumari PK. (1975): Induction of male sterility by gibberellic acid in sunflower. Indian J Genet Plant Breed, 35(1): 136-138.

Sharpe RM, Donachie $K$ and Cooper I. (1988): Re-evaluation of the intratesticular level of testosterone required for quantitative maintenance of spermatogenesis in the rat. $\mathrm{J}$. Endocrinology, 117(1): 19-26.

Silverstone AL and Sun T (2000): Gibberellins and the green revolution. Trends Plant Sci., 5: 12.

Snedecor, G.W. and Cochran, W.G. (1976): Statistical Methods $6^{\text {th }}$ ed, Iowa State Univ. press, Ames, Iowa, U.S.A.; 161-166.

Sun YT, Wreford NG, Robertson DM, et al. (1990): Quantitative cytological studies of spermatogenesis in intact and hypophysectomized rats: Identification of androgen dependent stages. Endocrinology, 127: 1215-1223.

Tomlin CDS. (2004): Gibberellic acid. In: Tomlin CDS (Eds.). The pesticide manual. $13^{\text {th }}$ ed. 
Hampshire, UK: British Crop and gibberellic acid on serum Protection Council, 3: 5-6.

Trinder, P. (1969): Determination of blood glucose using an oxidaseperoxidase system with a non-carcinogenic chromogen. J. Clin. Path. 22 (2): 158-161.

Troudi A, Ben Amara I, Soudani $\mathbf{N}$, Samet AM and Zeghal $N$ (2011): Oxidative stress induced by gibberellic acid on kidney tissue of female rats and their progeny: biochemical and histopathological studies. J Phys Biochem 67:307316.

Troudi A, Samet AM and Zeghal N. (2010): Hepatotoxicity induced by gibberellic acid in adult rats and their progeny. Exp Toxicol Pathol.; 62(6): 637-642.

Tuluce $Y$ and Celik I (2006): Influence of subacute and subchronic treatment of abcisic acid marker enzymes and erythrocyte and tissue antioxidant defense systems and lipid peroxidation in rats. Pest Biochem

Physiol., 86:85-92.

Ustan H, Tecimer T, Ozmen M, et al. (1992): Effects of gibberellic acid and benzoprenin on mice. Hispathologic Rev Ank Patho Bult; 9: 36-40.

Vesely, D.L., Hudson, J.L. pipkin, L.D.Pack and S.Meiners (1995): Plant growth- promoting hormones activate mammalian granulate cyclase activity. Endocrinology, 116 (5): 1887-1892.

Wafaa FH, Fatma YF, Marwa AA and Azza SS (2011): Hepatotoxic potential of Gibberellic acid in adult male albino rats. Life Sci. J., 8:373-383 